\title{
The Impact of Corporate Strategies on Financial Leverage: Evidence From Turkish- Listed Firms $^{1}$
}

\author{
Ahmed Ibrahim Abdelhadi HOUR iDa Burcu DİNÇERGÖK ${ }^{\text {IDa }}$ \\ aAtilim University, Graduate school of social sciences, Ankara, Turkey. Ahmethoor90@gmail.com \\ bAtilim university, School of Business, Ankara, Turkey burcu.dincergok@atilim.edu.tr
}

\begin{tabular}{ll}
\hline ARTICLE INFO & ABSTRACT \\
\hline $\begin{array}{l}\text { Keywords: } \\
\text { Corporate Strategy }\end{array}$ & $\begin{array}{l}\text { Purpose - The study aims to carry out empirical testing to analyze the impact of corporate strategies } \\
\text { (internationalization, diversification) on financial decisions for non-financial Turkish listed firms. } \\
\text { Capital Structure }\end{array}$ \\
$\begin{array}{l}\text { Internationalization } \\
\text { Diversification }\end{array}$ & $\begin{array}{l}\text { internationalization and diversification strategies on leverage ratio of Turkish firms. Data is collected from } \\
\text { hundred fifty-three non-financial organizations that are listed on the Borsa Istanbul Stock Exchange (ISE) } \\
\text { between 2003-2018. }\end{array}$
\end{tabular}

Received 13October 2021

Revised 12November 2021

Accepted 5 December 2021

Article Classification:

Research Article
Finding - The outcomes of this study provide empirical evidence that internationalization and diversification have significant positive impacts on debt level of Turkish organizations. Moreover, liquidity, non-debt tax shield, tangibility, and profitability have significant negative effect on debt ratio of non-financial Turkish firms. The findings of this paper also suggest that size, growth opportunity, and ownership concentration have positive and significant effect on debt ratio of Turkish firms.

Discussing - Considering a wide range of the financial literature that recognized capital structure as a crucial subject, most of the literature addressed the relations between firm-specific characteristics and financial leverage, a few studies focused on the relation between corporate strategy and a firm's leverage in developed and emerging countries' economics. Unfortunately, Turkey has been neglected in this field. To do so, this study considered the effect of two corporate strategies - internationalization and diversification strategies - and seven more factors potentially influencing the capital structure of Turkish firms.

\section{INTRODUCTION}

Capital structure has attracted academic attention and sparked an intense debate in the field of financial management for decades. Capital structure has been a highly debatable topic since Modigliani and Merton Miller (MM), in 1958, set a precedent that the value of the organization is not affected by its capital structure. The percentage of debt an organization uses in its capital structure is called financial leverage (Gill \& Mathur, 2011). It can be stated that the blend between debt and equity that is used to fund the growth and operations of an organizations is capital structure (Dirk et al., 2006). While equity can be retained earnings, preferred stock, or common stock, debt is referred to as funds that are sourced from financial institutions or a debt holder. To explain factors that may affect financial decisions, most previous studies focused on a firm's characteristics as determining factor of capital structure (Ozkan, 2001; Sayılgan et al., 2006; Bayrakdaroğlu et al., 2013; Acaravci, 2015). Other scholars (Barton \& Gordon, 1988; Lee \& Kwok, 1988; Lowe et al., 1994; Chuang et al., 1999), however, link corporate strategy to financial leverage to explain capital structure from the behavioral perspective; this approach also allows to understand the capital structure from the managerial decision perspective. Nevertheless, corporate strategies have been subject to more attention and are being adopted in recent years due to the highly competitive environment as a result of globalization. Corporate strategy is one of the three levels of strategy for any organization: functional, business, and corporate. At the corporate level, the strategy can be structured for the whole organization. Moreover, strategy comprises dealing with multiple business domains and taking critical decisions in them. At the business unit level, strategies are focus on how to turn the company's vision into reality. At the functional level, the strategy is

1This article is produced from the Ph.D thesis of Ahmed Hour in Atilim university. Graduate school of social sciences 
applied to convert the business unit level objectives and goals, using the strengths and capabilities of the company. According to Harrison (2003), there are four generic types of corporate strategies: growth, stability, retrenchment, and combination strategy. Our study focuses on the corporate growth strategy, which further has different types of strategies that firms can adopt as per their characteristics and environment. According to Ansoff (1965), the four main corporate growth strategies are integration, diversification, product development, and internationalization.

Several studies have explained the influence of corporate strategy on an organization's financial decisions; Majority of these studies used one type of corporate strategy at a time. Some of them used internationalization as a dimension of corporate strategy (Williamson, 1988; Chkir\& Cosset, 2003; Singh \&Nejadmalayeri, 2004; Lindner et al., 2018; Duran \&Stephen, 2020), whereas several other studies focused on diversification (Singh et al., 2003; Rocca et al., 2009; Jouida, 2018; Dinh et al., 2019).A few studies associated integration with a firm's capital structure( Javorcik \& Spatareanu, 2009; Lucey \&Zhang, 2011). On the other hand, some researchers used more than one dimension of corporate strategy in their studies. Low and Chen (2004) focused on internationalization and diversification; Cappa et al. (2020) investigated how capital structure is impacted by diversification, integration, and internationalization.

The contributing value of this research is achieved through adopting behavioral theory principles of capital structure to investigate the relationship between corporate strategy and leverage. Thereby extending recent studies that focused on firms' characteristics as determining factor of capital structure. Furthermore, previous studies, within the listed Turkish organizations context, focused only on one dimension of corporate strategy, or they mixed internationalization with diversification by focusing on multinational diversified firms. However, our research will be the first study in Turkey to consider two types of corporate strategy (internationalization and diversification) simultaneously and independently, to give a clear picture of the influence of corporate strategy on leverage ratio for Turkish-listed organizations. The financial crisis, globalization, and changes in international politics that the world experienced in the past twenty years have increased competition, especially in emerging countries' markets. Moreover, the strategic choices of firms are changing due to the rapidly changing digital technologies and innovation advancements (Dobusch \& Kapeller, 2018). Keeping these aspects in perspective, there is a need to re-examine the factors that could impact an organization's leverage ratio. To do so, we focused on the impact of corporate strategy (diversification and internationalization) on financial leverage through empirical evidence.

We organized our paper to present the theoretical framework of the variables and their relationships and develop the hypothesis that can describe it according to available analyses. Subsequently, we provide the methodology of the study, including variables, model of the study, sample, and the data collection methods. After study application, we report the results and statistical analysis. Finally, findings are discussed based on empirical data, and the last section presents the findings, conclusions, and limitations of this research.

\section{Theoretical Framework and Hypotheses Structuring}

The concept of corporate strategy has three main sub-dimensions: internationalization, diversification, and integration. Internationalization and diversification strategies have a significant role in the strategic behavior of large organizations, and are vital determinants of capital structure (Hitt et al., 1994). In this study, only internationalization and diversification were chosen as dimensions of corporate strategy. The following sections narrate the characteristics of the relationships between these two dimensions and capital structure.

\subsection{Internationalization and capital structure}

The concept of internationalization has evolved in the last decades. Internationalization refers to the process in which the organizations progressively expand their operations in the international market or across national boundaries (Johanson\& Vahlne, 1977; Welch \&Luostarinen, 1988; Kwok \&Reeb, 2000; Yeyati\&Micco, 2007). Theories that explained the impact of internationalization strategy on a firm's financial leverage provide conflicting predictions; each theory has its own perspectives. The agency theory (Jensen \&Meckling, 1976) predicts a negative impact of organization internationalization on its leverage ratio. An international firm's investors face issues in gathering and processing information, which make investing in international firms difficult, and costs more as compared to domestic businesses. Additionally, due to high costs of auditing, differences legal structures, and cultural variations, debt holders would ask for higher interest payments on 
debts of international firms. Hence, it would be more costly for international firms to borrow than domestic firms. Thus, international firms tend to characterize their capital structure with less debt because of the higher cost of it (Doukas \& Pantzalis, 2003). A few studies were consistent with the agency theory's expectations; their findings detected a negative relationship of internationalization with debt ratio (Kim \& Lyn, 2003; Doukas \& Pantzalis, 2003; Cappa et al., 2020). In contrast, the trade-off theory, which states than an organization's financial leverage is to be defined by a trade-off between tax shields of debt, and financial distress, and agency costs, predicts a positive impact of the organization's internationalization and leverage ratio (Mansi \& Reeb, 2002). International organizations can own subsidiaries in different locations with advantageous tax rates or interest deduction laws; thus, they are more able to increase their tax shield advantages (Joliet \& Muller, 2013). Internationalization also creates cash flow diversification. Most of the previous studies with empirical approaches confirmed the predictions of the trade-off theory, and they found internationalization and leverage ratio positively correlated, especially in developing countries (Heston \& Rouwenhorst, 1994; Mansi \& Reeb, 2002; Gönenç \& Arslan, 2003; Singh \& Nejadmalayeri, 2004; Gonenc \& Haan, 2014; Wyrobek \& Lane, 2019; Duran \& Stephen, 2020). Gönenç and Arslan (2003) found that internationalization and debt ratios are positively correlated in the Turkish market. Moreover, Gonenc and Haan (2014) results detected international firms in developing countries have high debt levels in comparison with domestics ones, as result, we expect Turkish international organizations to have greater debt levels in their financial leverage than domestic firms. The first hypothesis is proposed based on the aforementioned literature findings.

\section{$H_{1}$ : The internationalization strategy has a positive impact on the financial leverage of non-financial Turkish-listed firms}

\subsection{Diversification and capital structure}

The diversification strategy (product diversification), according to previous literature, can be further classified into two types, namely related and unrelated diversification. Unrelated diversification shows the extent to which a company's activities are dispersed across different industries, whereas related diversification implies the dispersion of a firm throughout business segments (Rumelt, 1974). Firms that are located in developed economies are more likely to use related diversification, while unrelated diversification is more applicable in emerging markets (Purkayastha et al., 2012). Furthermore, regarding the correlation of diversification with debt ratio, diversification can affect the financial leverage of an organization in three ways: co-insurance effect, transaction cost explanation, and agency theory. According to the co-insurance effect, diversification capable of improving a firm's debt capacity through a reduction in business risks. It is argued that diversified activities of an organization can help to decrease the risks of operating through single domain, and these organizations are supposed to utilize more debt due to the benefits of the fiscal advantages related to debt (Kim \& McConnell, 1977). Similarly, Bergh (1997) noted that the co-insurance effect is more applicable for unrelated diversification strategies due to the low correspondence among different industries. Bergh (1997) also mentioned that diversification strategies will result in more debt usage compared to non-diversified ones. Based on these arguments, the co-insurance effect expected a positive correlation of the diversification strategy with debt ratio (Menendez-Alonso, 2010).

Based on the transaction cost explanation, unutilized assets are the main motives for companies to their activities (Menendez-Alonso, 2010). The transaction cost explanation investigates the financial decision of an organization according to its specific degree of assets (Williamson, 1988). For an organization with an increased specificity of assets, equity is the preferred financial tool, as the ability to redeploy these assets is limited, and, hence, they have low values as collateral assets in the scenario of liquidation. Additionally, for an organization with no specificity in assets, debt is the preferred financial instrument. Therefore, this approach suggests that related diversified firms tend to employ equity more than debt, while unrelated diversified firms are supposed to rely on debt more than equity. Thus, the transaction cost explanation predicts a negative effect of related diversification on leverage and a positive correlation of unrelated diversification with debt ratio.

Agency cost theory provides further explanation about the impact of diversification on financial leverage. The concept seeks explaining the conflict between the views of manager and shareholders (Jensen, 1986). One way 
to reconcile this conflict, as for the theory, is to consider debt financing. This suggests that firms should rely on borrowing money to finance expansion and precluding managers from making less efficient decisions, thus burying the fears of bad diversification decisions undertaken by managers. This means, among other things, that the debt ratio is positively correlated with diversification strategies (Rocca et al., 2009). Jensen, (1986) predicts a positive impact of diversification on debt ratio, he argued that using debt as a discipline tool on managerial behavior can reduce the managerial freehand of free cash flow. Thus, the concept reinforces the perspective that debt has a positive role in reducing manager's ability to recognize the detrimental diversification strategies. As a result, the effect of diversification strategy on financial decisions can be explained through the monitoring effect (Rocca et al., 2009).

However, a few studies (Singh et al., 2003, Alonso, 2003; Rocca et al., 2009; Lim \& Das, 2009; Ajay \& Madhumathi, 2012; Joudia \& Hellara, 2018; Benz \&Hoang, 2019; Cappa et al., 2019) have related diversification to financial decisions. Rocca et al. (2009) discovered that the effect of diversification on financial leverage varies between related and unrelated diversification. Despite the positive effect of unrelated on leverage, debt ratio is affected negatively by related diversification. Additionally, Cappa et al. (2020) measured diversification based on the Herfindahl index of industrial concentration and concluded that diversification has a positive correlation with financial leverage. The second hypothesis is proposed based on the aforementioned literature findings.

\section{$\mathrm{H}_{2}$ : The diversification strategy has a positive impact on the leverage ratio of non-financial Turkish-listed} firms.

\subsection{Other determining factors of capital structure}

The literature is extensive as it approaches determining factors of capital structure. Most studies emphasized the role of size, profitability, liquidity, growth opportunities, tangibility, non-debt tax shields, and ownership concentration on capital structure determination ( Miguel \& Pindado, 2001; Daskalakis \& Psillaki, 2008; Wahab \& Ramli, 2013; Acedo-Ramírez \& Ruiz-Cabestre, 2014; Acaravci, 2015) Besides the main variables of diversification and internationalization, the variables listed above were chosen as control variables in our study, which are separately examined accordingly.

\section{Size}

Research show that the size of a firm affects its leverage ratio. A negative relationship of the size of an organization with its debt ratio is suggested by the pecking order theory suggests, which argues that large firms are supposed to finance their leverage by equity more than debt, due to the higher capability of issuing equity and the lower information asymmetry compared to smaller ones (Kashefi-Pour et al., 2010). Some empirical research supported the concept's prediction that leverage is negatively influenced by a firm's size (Wald, 1999; Attar, 2014; Cappa et al., 2020). Alternatively, the trade-off theory suggests that big organizations are supposed to have higher debts in their capital structure caused by lower non-payment risk (Myesrs, 1984). Large firms increase their amount of debt because they're expected a lower bankruptcy cost (Rajanand \& Zinglales, 1995). Thus, the trade-off theory suggests a positive correlation between debt ratio and the size of the organization. Majority of research supported the trade-off theory's perspective (Rajan \& Zingales, 1995; Gönenç \& Arslan, 2003; Gaud et al., 2005; Sayilgan et al., 2006; Tomak, 2013; Bayrakdaroğlu et al., 2013; Acaravci, 2015; Coleman et al., 2016; Singh, 2016; Dinçergök, 2017), their results detected that size of a firm affect leverage positively.

\section{Profitability}

There are conflicting predictions profitability's impact on capital structure. As per trade-off theory, the organization's profitability, and leverage are positively correlated. Profitable organizations have better borrowing capabilities due to their greater ability to paying back their loans (Gaud et al., 2005). Furthermore, profitable organizations have higher revenues to shield from taxes. Therefore, they could have benefited debt's tax advantage (Huang \& Song, 2006). Similarly, the agency cost theory predicted a positive correlation between profitability on the debt ratio. It argued that organizations with higher profits may face serious free cash flow problems, thus, high debt could be utilized to lessen these problems (Jensen, 1986). Subsequently, a 
few empirical studies identified a positive correlation between the two variables (Taub, 1975; Fattouh et al., 2002; Munene, 2006). In contrast, from pecking order theory's proposition leverage and profitability are negatively correlated; it claims that profitable organizations prioritize using internal financing to avoid the cost of external financing and reducing information asymmetries (Myers \& Majluf, 1984). Consequently, most of the empirical research that investigated the impact of profitability on financial leverage supported the Pecking order theory's prediction and concluded with negative relationship between profitability and leverage (Ozkan, 2001; Gönenç \& Arslan, 2003; Tong \& Green, 2007; Sayilgan et al., 2006; Acaravci, 2015; Bayrakdaroğlu et al., 2013; Cappa et al., 2020).

\section{Liquidity}

The liquidity ratio of organizations has two contradictory impacts on the organization's financial decisions. The trade-off theory expects organizations with more liquid assets to meet their commitments, hence tending to use external funds with minimized costs. As a result, organizations with higher liquidity levels tend to have higher debt levels. Hence, the trade-off theory expects liquidity and leverage to have a positive correlation. A number of empirical studies (Bhaduri, 2002; Sibilkov, 2009; Umer, 2014; Pacheco \& Tavares, 2015; Shah\& Khan, 2017; Kirac1 \& Aydin, 2018) met the prediction of the trade-off theory and observed a positive relationship between the two variables. On the contrary, the pecking order theory predicts that an organization with higher liquidity level would have lower leverage ratio; this negative correlation is predicted because firms with high liquid assets should use their internal financing rather than debt (Deesomsak et al., 2004). Consequently, some empirical studies evidence that liquidity and leverage are negatively correlated (Deesomsak et al., 2004; Ali et al., 2011; Sbeti \& Moosa, 2012; Güner, 2015; Cevheroglu-Acar, 2018; Ramli et al., 2019).

\section{Growth opportunity}

Literature of finance suggests different explanations for the relationship of this variable with financial leverage. According to the agency theory, an organization with higher growth opportunities tends to employ less debt in aim to reducing conflict of interest between the shareholders and debt holders; this means less debt and more equity level. It is claimed that an organization with higher growth potentials is more inclined to utilize less debt due to their stronger motivation to evade underinvestment and asset substitution caused by conflicts of bondholders and shareholders. Subsequently, the agency theory predicts growth opportunities and financial leverage to have a negative impact relationship (Myers, 1977; La Rocca et al., 2009). Similarly, the trade-off theory expected growth opportunity and debt ratio to be negatively correlated; it argues growth opportunity does not have collateral value and in case of bankruptcy this will lead to higher bankruptcy costs, however, organization that have high levels of growth opportunities will experience higher bankruptcy costs, which implies less amount of debt. Nevertheless, the pecking order theory suggests that growth potentials and leverage ratio demonstrate a positive correlational relationship. It argues that organizations may look for external funds to finance their growth. As a result, organizations that have higher growth opportunities potentially have higher debt levels (Myers, 1977). Some empirical studies were in the line with the predictions of trade-off theory and agency theory, and they found a negative correlation between growth opportunities and leverage (Brush et al., 2000; Chen, 2003; Arsov\&Naumoski, 2016). In contrast, some other studies supported the prediction of the pecking order theory, where the findings detected that growth opportunity and capital structure have a positive correlation (Sayilgan et al., 2006; Bayrakdaroğlu et al., 2013; Köksal et al., 2013; Acaravc1, 2015). We used the growth in total assets to examine if growth opportunity has an effect on the financial leverage.

\section{Non-debt tax shield (NDTS)}

Non-debt tax shield shows certain impact on the debt tax shield, where it emerges long-term deferred expenses, amortization, and tax reduction due to depreciation causing tax reductions. The non-debt tax shields involve accelerated depreciation and investment tax credits (Allen \& Mizono, 1989). DeAngelo and Masulis (1980) argue that tax benefits of debt financing are substituted by non-tax debt shields; thus, the tax reductions investment tax credits and depreciation could be used instead of tax benefits of debt financing. Companies with higher non-debt tax shields usually predict having reduced leverage than those with lower non-debt tax shields. As a result, DeAngelo and Masulis (1980) found that NDTS is negatively correlated with debt ratio. Most empirical studies examined were in the line with the predictions of DeAngelo and Masulis (1980), and 
they reported leverage and non-debt tax shields to be correlated negatively (Miguel \&Pindado, 2001; Ozkan, 2001; Sayilgan et al., 2006; Bayrakdaroğlu et al., 2013; Ramli et al., 2016). On the other hand, other literature (Wiwattanakantang, 1999; Bauer, 2004; Ramli et al., 2016) expected the opposite; they evidenced a positive relationship between the non-debt tax shield and leverage. Bradley et al. (1984) reported a significant positive relationship between non-debt tax shield and a firm's level of debt. In the same vein Graham, (203) argued that heavy investments in tangible assets is more effective in generating higher levels of depreciation and tax credits, leading to higher debt levels.

\section{Tangibility}

Tangibility is considered a significant determining factor of capital structure. Agency theory and trade-off theory mutually expect a positive impact on the leverage ratio, as it is easier to collateralize tangible assets and that endure value losses in financial distress. The value of tangible assets is higher than intangible assets at bankruptcy. Therefore, tangible assets could affect the borrowing decisions of a company, and subsequently, high tangibility leads to increased borrowing ability (Guad et al., 2005). Moreover, lender become more willing to offer funds and high leverage values proportionally with tangibility levels recorded on balance sheets (Rajan \& Zingales, 1995; Hardiningsih \& Oktaviani, 2012). Hence, tangibility is positively correlated with the leverage ratio (Stohs \& Mauer, 1996). In other words, organizations with fixed assets of higher value are more inclined towards having more debts. Conversely, companies with a lower level of tangibility have less ability to be able to guarantee their debt in the long term (Laksana \& Widyawati, 2016). Several empirical studies (Rajan \& Zingales, 1995; Hardiningsih \& Oktaviani, 2012; Iswarini \& Ardiansari, 2018) confirm the prediction of the trade-off theory and have indicated that leverage and tangibility are positively correlated. In contrast, pecking order theory suggests that an organization with higher tangibility level would have fewer information asymmetry problems, this means easier to issue equity (Harris \& Raviv, 1991). Thus, the pecking order theory predicted leverage and tangibility to be negatively correlated. Some previous studies (Gönenç \& Arslan, 2003; Sayilgan et al., 2006; Arilyn, 2020; Bayrakdaroğlu et al., 2013; Demirhan, 2009) supported the pecking order theory's proposition; their results showed that tangibility affected debt ratio negatively.

\section{Ownership concentration}

The ownership structure is considered a key determining factor of corporate governance due to its impact on the motivations of managers and subsequently organizational efficiency. The direction of correlation among ownership concentration and financial leverage varies among different theories. First, the monitoring argument stated that monitoring and controlling of management is more effective by large shareholders. Therefore, debt is one of the internal disciplinary tools, can be used by shareholders to reduce investments in non-profit projects (Pindado \& La Torre, 2011). Second, if firms have small shareholders, usually managers have the power to control and monitoring the financial decisions and to avoid bankruptcy risk managers tend to use less debt. Consequently, it can be said that large shareholders make it hard for managers to determine leverage according to their objectives (Friend \& Lang, 1988). Finally, if a firm is highly concentrated in ownership and power lies with a party that likes to use power - family or government ownership - to not lose this power, debt financing is preferred (Driffield et al., 2007). In contrast, some other literature predicted a negative impact of ownership concentration on financial leverage caused by substitution and expropriation. The substitution hypothesis argues that changes in the disciplinarily of debt is monitored and controlled by major shareholders (Grier \& Zychowicz, 1994). For the expropriation argument, it is argued that when cashflow rights of major stakeholders are exceeded by their control rights, they try to requisition minority shareholders, either by transferred resources from the company or by investing in unprofitable projects for their interests. Therefore, they prefer to avoid credit monitoring (Shleifer \& Vishny, 1986; Johnson et al., 2000).Several empirical studies have examined correlations between ownership concentration and capital structure. Some of these studies show positive correlation between ownership concentration and on organization's capital structure (Gönenç\& Arslan, 2003; Pindado\& La Torre, 2011; Ozili \& Uadiale, 2017; Migliardo \& Forgione, 2018). On the other hand, some others (Omet, 2006; Lin \& Zhang, 2009; Stancic et al., 2014; Boussaada et al., 2015; Ceylan, 2018) found ownership concentration negatively correlated with debt ratio. 


\section{Research Methodology}

\subsection{Sample and data collection}

The sample of this study comprised non-financial organizations listed on the Borsa Istanbul Stock Exchange (ISE) between 2003-2018. Financial, insurance, and firms with incomplete observation in any year of the analyzed period were eliminated from the study; thus, the sample consisted of a balanced panel of 153 organizations (2,448 observations), which is $66 \%$ of the total population. Data were gathered from Thomson Reuters Eikon database and the Public disclosure platform (KAP)

\subsection{Variables}

The debt ratio was chosen as a measurement tool for financial leverage, which is the dependent variable in our model (TDTA). Previous studies used various measurements as an alternative to financial leverage (debt ratio). Financial leverage is used by the ratio dividing total debt by net assets (Rajan \& Zingales, 1995). Some other studies used the ratio of total debt over equity (Sayilgan et al., 2006; Abdul-Qadir et al., 2015). Leverage was also calculated using the ratio of total liabilities to total assets (Oktovianti \& Agustia, 2012) and by longterm debt to total assets (Ahmad pour et al., 2012), and by total debt to total assets (Puragand Abdullah, 2016; Nguyen, 2020). In our study, we used the totals debt to assets ratio to measure the leverage ratio.

Internationalization (INTER) is assumed as first independent variable, and foreign sales over total sales is assumed to be a scale for internationalization in our study. Similar to the study of Gönenç and Arslan (2003) firms are accepted as international if the ratio of foreign revenue to the total revenue was equal to or more than $10 \%$, the dummy variable was 1 for international firms and 0 for domestic ones.

The second independent variable is diversification. Generally, the SIC system and Nace code classifications are used as a measurement of diversification, which has been evidenced by various studies (Amit \& Livnat, 1989). Since our study focused on Turkish firms, and due to the lack of coding for Turkish firms, we proxies diversification (DIVERS) in Turkish firms based on the business summary of them by using NACE code classification Reverence 2. If an organization operates in multiple divisions, it is accepted as diversified; a firm that operates in only one division is to be accepted as non-diversified. The dummy variable used to measure diversification variable (DIVERS) assumes a value of ONE for diversified firms, while ZERO is assumed for non-diversified ones.

Several specific factors that may affect the financial leverage have been controlled in this study. We measure these factors as follows:

- Ownership concentration: considering the three main shareholders, their total percentage share is used to measure the ownership concentration variable (owner).

- Tangibility: The ratio of fixed to total assets (fixed /total) is calculated to measure tangibility variable (TANG).

- Non-debt tax shield: The ratio of annual depreciation expense to total assets is used to measure the (NDTS) variable.

- Growth opportunity: The ratio of the percentage change in total assets is used to measure growth opportunity in the total assets variable (GROW)

- Liquidity: Current assets to current liabilities are used to measure liquidity variable (LIQUID).

- Profitability: The ROA to total assets, which is calculated through the net income rate after tax to total assets, measures profitability variable (PROF).

- Size of the firm: The natural log value of total assets represents the size variable (SIZE).

\subsection{Research Model}

We estimate the following model using panel data analysis to examine the effect of our independent variables on our dependent variable (TDTA) at time $t$ :

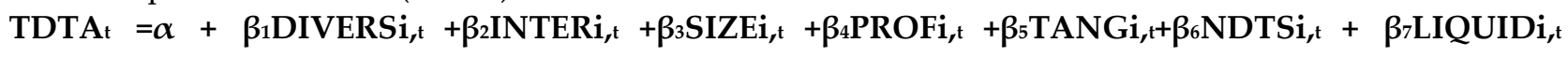
$+\beta_{8}$ GROWi,$t+\beta_{9}$ OWNERi, $t+\varepsilon$, 
Where TDTA $t$ is the financial leverage of a firm $i$ at time $t$, DIVERS $t$ is diversification at time $t$, INTERt is internationalization at time $t$, SIZE is the size of firm $i$ at time $t$, PROF is the profitability of firm $i$ at time $t$, TANG $\mathrm{t}_{\mathrm{i}}$ the tangibility of firm $i$ at time $t$, NDTS represents non-debt tax shields of firms $i$ at time $t$, LIQUID $t$ is the liquidity of firm $i$ at time $t, G R O W_{t}$ is the growth opportunity of assets at time $t$ and OWNER $\mathrm{t}_{\mathrm{t}}$ the ownership concentration of firm $i$ at time $t$.

\section{Finding of Study}

The descriptive statistics for the dataset is reported in Table 1 for all research variables. The findings of the leverage variable (TDTA) show that Turkish firms use approximately $27 \%$ debt. The mean of internationalization shows that $58 \%$ of Turkish firms are international firms. The average of diversification is around $42 \%$. The descriptive statistics of our control variable show that the mean of ownership concentration is around $65 \%$, which indicates that Turkish firms are highly concentrated, the average size of Turkish firms is around 5.7 , liquidity is 2.08 , profitability is almost $6 \%$, tangibility is around $34 \%$, growth opportunity of Turkish firms is $20 \%$, and non-debt tax shield is around $4 \%$.

Table1. Descriptive Statistics

\begin{tabular}{|l|c|l|c|c|c|}
\hline Variable & $\begin{array}{c}\text { Number of } \\
\text { Observed } \\
\text { Organizations }\end{array}$ & Average & SD & Min. & Max. \\
\hline TDTA & 2448 & 0.2685 & 0.2020 & 0 & 1.604 \\
\hline INTER & 2448 & 0.5755 & 0.4943 & 0 & 1 \\
\hline DIVERS & 2448 & 0.4240 & 0.4942 & 0 & 1 \\
\hline OWNER & 2448 & 0.6548 & 0.1807 & 0.114 & 1 \\
\hline SIZE & 2448 & 5.7078 & 1.6224 & 0.7884 & 9.964 \\
\hline LIQUID & 2448 & 2.0801 & 1.7491 & 0.0393 & 8.975 \\
\hline PROF & 2448 & 0.0551 & 0.1724 & -1.401 & 2.697 \\
\hline TANG & 2448 & 0.3443 & 0.2051 & 0.0001 & 1.414 \\
\hline NDTS & 2448 & 0.0397 & 0.0735 & 0 & 1.497 \\
\hline GROW & 2448 & 0.2060 & 0.2125 & -0.1208 & 0.9999 \\
\hline
\end{tabular}

Note: TDTA $=$ debt ratio; INTER $=$ internationalization; DIVERS diversified; OWNER $=$ ownership concentration; LIQUID = liquidity; TANG = tangibility; $\mathrm{PROF}=$ profitability; NDTS= non debt tax shield; GROW $=$ growth opportunities of assets.

The results of the correlational analysis on the relationships between the ten variables is reported in Table 2 . The correlation matrix indicate that all coefficients were less than 0.7 which means there is no existence of multicollinearity in our model as mentioned across existing literature (Lehmann et al., 1997; Cappa et al., 2019).

Table2. Pearson Correlation Matrix

\begin{tabular}{|l|l|l|l|l|l|l|l|l|l|l|}
\hline & TDT & INTE & DIVE & OW & SIZ & LIQU & PRO & TAN & NDT & GR \\
\hline TDTA & 1.000 & & & & & & & & & \\
\hline INTER & $.096^{*}$ & 1.000 & & & & & & & & \\
\hline DIVERS & $.225^{*}$ & $.069^{*}$ & 1.000 & & & & & & & \\
\hline OWNE & $-.008^{*}$ & $.043^{*}$ & $.053^{*}$ & 1.000 & & & & & & \\
\hline SIZE & $.170^{*}$ & $.084^{*}$ & $.092^{*}$ & $.168^{*}$ & 1.00 & & & & & \\
\hline LIQUID & $-.326^{*}$ & $-.007^{*}$ & $-.044^{*}$ & $.003^{*}$ & - & 1.000 & & & & \\
\hline PROF & $-.239^{*}$ & $.095^{*}$ & $-.031^{*}$ & .092 & $.009^{*}$ & $.249^{*}$ & 1.000 & & & \\
\hline TANG & $-.017^{*}$ & $.049^{*}$ & $-.084^{*}$ & $-.010^{*}$ & $.045^{*}$ & $-.097^{*}$ & $-.055^{*}$ & 1.000 & & \\
\hline NDTS & $-.007^{*}$ & $.055^{*}$ & $.005^{*}$ & $.035^{*}$ & - & $-.044^{*}$ & $-.081^{*}$ & $.097^{*}$ & 1.000 & \\
\hline GROW & $.092^{*}$ & $-.056^{*}$ & $.014^{*}$ & $-.030^{*}$ & - & $-.085^{*}$ & $.058^{*}$ & $-.071^{*}$ & $.011^{*}$ & 1.000 \\
\hline
\end{tabular}

Following standards that have been done by Namara (2017), we addressed the Breusch-Pagan test to check whether panel data or cross-sectional regression is consistent with our data. Table 3 shows the results of the Breusch-Pagan analysis. 
Table3. Breusch - Pagan Analysis

\begin{tabular}{|l|l|l|}
\hline Estimated results & Var & Sd= sqart (var) \\
\hline TDTA & .04083 & 0.2020 \\
\hline E & .01530 & 0.1237 \\
\hline U & .01553 & 0.1246 \\
\hline Test & Var $(\mathrm{u})=0$ & \\
\hline Chibar2(0) & 4325.0 & \\
\hline Liq & 0.000 & \\
\hline
\end{tabular}

Findings of the Breusch-Pagan analysis show the suitability of panel analysis in comparison with a crosssectional regression for our data. Based on that, the Hausman test should be used to analyze whether our data is explained using the models of fixed or random effects, following what has been carried out by previous studies (Jaisinghani, 2015). However, the Hausman test is only valid under homoscedasticity (Schmidheiny, 2017). Thus, we employed the Breusch-Pagan test to check whether our data are homoscedastic or not (Pagan \& Hall, 1983; Cappa et al., 2019). The results of the Breusch-Pagan test evidenced that there are no heteroscedasticity problems in our panel data, as reported in Table 4

\section{Table 4. Breusch-Pagan Test for Heteroskedasticity}

\begin{tabular}{|l|c|}
\hline H0: & constant variance (homoscedasticity) \\
\hline H1: & at least one variable has heteroscedasticity \\
\hline Chi2 (9) $=$ & 3.10 \\
\hline Prob $>$ chi2 $=$ & 0.0785 \\
\hline
\end{tabular}

The results of the Breusch-Pagan analysis in Table4 suggest that Prob $>\mathrm{F}$ exceeds 0.05 ; thus, the null hypothesis is accepted. Subsequently, our panel data is characterized by homoscedasticity. We also checked the stationarity of our variable, which is an important assumption for panel regressions, with the Fisher test to check whether we have unit-root problems in our panel data; Table 5 shows the findings of Fisher analysis.

Table 5. Fisher Analysis for Stationary of panel data

\begin{tabular}{|l|l|l|l|l|}
\hline & Inverse chi-Sq & Inverse Nor & Inverse Logit & Modified Chi-sq \\
\hline P-valueTDTA & 0.0000 & 0.0001 & 0.0000 & 0.0000 \\
\hline p-valueINTER & 0.0013 & 0.0000 & 0.0000 & 0.0006 \\
\hline p-valueDIVERS & 0.0000 & 0.0000 & 0.0000 & 0.0000 \\
\hline p-valueOWNER & 0.0000 & 0.0007 & 0.0001 & 0.0000 \\
\hline p-valueSIZE & 0.0000 & 1.0000 & 1.0000 & 0.0000 \\
\hline p-valueLIQUID & 0.0000 & 0.0000 & 0.0000 & 0.0000 \\
\hline p-valuePROF & 0.0000 & 0.0000 & 0.0000 & 0.0000 \\
\hline p-valueTANG & 0.0000 & 0.0000 & 0.0000 & 0.0000 \\
\hline p-valueNDTS & 0.0000 & 0.0000 & 0.0000 & 0.0000 \\
\hline p-valueGROW & 0.0000 & 0.0000 & 0.0000 & 0.0000 \\
\hline Num. of panels & 153 & 153 & 153 & 153 \\
\hline Num. of periods & 16 & 16 & 16 & 16 \\
\hline
\end{tabular}

The result of the Fisher analysis provided in Table 5 is deemed unacceptable $(p<0.01)$, which indicates that the data is stationary, thus fitting with panel regression. After testing heteroscedasticity and stationarity, we employed the Hausman test to check the suitability of the panel with either fixed or random models. Table 6 shows the findings of Hausman analysis. 
Table 6. Hausman Analysis

\begin{tabular}{|c|c|c|c|}
\hline Hausman Test & $\begin{array}{l}\text { Coefficients - } \\
\text { (A) } \\
\text { FIXED }\end{array}$ & $\begin{array}{l}\text { (B) } \\
\text { RANDOM }\end{array}$ & $\begin{array}{l}(\mathrm{A}-\mathrm{B}) \\
\text { Difference }\end{array}$ \\
\hline INTER & 0.04238 & 0.04210 & 0.00027 \\
\hline DIVERS & 0.36990 & 0.07895 & 0.29094 \\
\hline OWNER & 0.07159 & 0.04273 & 0.02885 \\
\hline SIZE & 0.06029 & 0.04804 & 0.01225 \\
\hline LIQUID & -0.01780 & -0.01942 & 0.00162 \\
\hline PROF & -0.26687 & -0.26855 & 0.00167 \\
\hline TANG & -0.09974 & -0.10511 & 0.00532 \\
\hline NDTS & -0.09046 & -0.12738 & 0.03691 \\
\hline GROW & 0.02614 & 0.03193 & -0.00577 \\
\hline Test & \multicolumn{3}{|c|}{ H0: difference in coefficient not systematic } \\
\hline Chi2 (9) & \multicolumn{3}{|l|}{71.66} \\
\hline Prob $>$ chi 2 & \multicolumn{3}{|l|}{0.001} \\
\hline
\end{tabular}

Based on the findings from Hausman analysis, the fixed effect model was used in our study. Following the main model (Model1); we derived four models; In Model 1, the analysis is conducted using all of the variables. The model's coefficient of determination $\left(R^{2}\right)$ is $24 \%$. Alternatively, the independent variables used in our model can explain $24 \%$ of the variation of the leverage ratio. Model 2 and Model 3 analyze diversification and internationalization respectively. The $\mathrm{R}^{2} \mathrm{~s}$ of Model 2 and 3 are 23.7 and 23.8\% respectively; which are quite close. The $\mathrm{R}^{2}$ of the last model - which only uses the control variables - is $23 \%$. In all the models, the chisquared test was significant at the $5 \%$ level, which proved that our models are valid. The findings from panel data analysis are shown in Table 7, and they indicate significant positive relationship between corporate strategies (diversification and internationalization) and the capital structure.

Table 7. Fixed Effect model, Panel Data Regression Results

\begin{tabular}{|c|c|c|c|c|}
\hline Variable & Model1 & Model2 & Model3 & Model4 \\
\hline INTER & $\begin{array}{c}.04238^{* * *} \\
(0.000)\end{array}$ & & $\begin{array}{c}.04248^{* * * *} \\
(0.000)\end{array}$ & \\
\hline DIVERS & $\begin{array}{c}.36990^{* * *} \\
(0.000)\end{array}$ & $\begin{array}{c}.36887^{* * *} \\
(0.000)\end{array}$ & & \\
\hline OWNER & $\begin{array}{c}.07159^{* *} \\
(0.026)\end{array}$ & $\begin{array}{c}.07147^{* *} \\
(0.027)\end{array}$ & $\begin{array}{c}.07095^{* *} \\
(0.028)\end{array}$ & $\begin{array}{c}.07084^{* *} \\
(0.029)\end{array}$ \\
\hline LIQUID & $\begin{array}{c}-.01778^{* * *} \\
(0.000)\end{array}$ & $\begin{array}{c}-.01820^{* * * *} \\
(0.000)\end{array}$ & $\begin{array}{c}-.01778^{* * *} \\
(0.000)\end{array}$ & $\begin{aligned}- & .06237^{* * *} \\
& (0.000)\end{aligned}$ \\
\hline SIZE & $\begin{array}{c}.06029^{* * * *} \\
(0.000)\end{array}$ & $\begin{array}{c}.06154^{* * *} \\
(0.000)\end{array}$ & $\begin{array}{c}.06105^{* * *} \\
(0.000)\end{array}$ & $\begin{array}{c}.01818^{* * *} \\
(0.000)\end{array}$ \\
\hline PROF & $\begin{array}{c}-.26687^{* * *} \\
(0.000)\end{array}$ & $\begin{array}{c}-0.2671^{* * *} \\
(0.000)\end{array}$ & $\begin{array}{c}-.26587^{* * *} \\
(0.000)\end{array}$ & $\begin{array}{c}-.26612^{* * *} \\
(0.000)\end{array}$ \\
\hline TANG & $\begin{array}{c}-.09974^{* * *} \\
(0.000)\end{array}$ & $\begin{array}{c}-.09870^{* * *} \\
(0.000)\end{array}$ & $\begin{array}{c}-.10116^{* * *} \\
(0.000)\end{array}$ & $\begin{array}{c}-.10012^{* * *} \\
(0.000)\end{array}$ \\
\hline NDTS & $\begin{array}{c}-.09046^{* *} \\
(0.035)\end{array}$ & $\begin{array}{c}-0.07631^{*} \\
(0.076)\end{array}$ & $\begin{array}{c}-.08889^{* *} \\
(0.039)\end{array}$ & $\begin{array}{c}-.07478^{*} \\
(0.083)\end{array}$ \\
\hline GROW & $\begin{array}{c}.02614^{* *} \\
(0.043)\end{array}$ & $\begin{array}{c}.02685^{* *} \\
(0.038)\end{array}$ & $.02507^{* *}(0.053)$ & $\begin{array}{c}.02578^{* *} \\
(0.047)\end{array}$ \\
\hline INTERCEPT & $\begin{array}{c}-.21952^{* * *} \\
(0.000)\end{array}$ & $\begin{array}{c}-.20195^{* * *} \\
(0.000)\end{array}$ & $\begin{array}{c}-.06597^{* *} \\
(0.047)\end{array}$ & $\begin{array}{c}-.04887^{* *} \\
(0.14)\end{array}$ \\
\hline
\end{tabular}




\begin{tabular}{|c|c|c|c|c|}
\hline Num. Obs & 2448 & 2448 & 2448 & 2448 \\
\hline Deg. of freedom & 9 & 8 & 8 & 7 \\
\hline $\mathbf{R}^{2}$ & 0.2436 & 0.2373 & 0.2380 & 0.2318 \\
\hline Pro $>$ chi $^{2}$ & 0.000 & 0.000 & 0.000 & 0.000 \\
\hline
\end{tabular}

Notes: ${ }^{*}$ significant at $10 \%$ level; ${ }^{* *}$ significant at $5 \%$ level; ${ }^{* * *}$ significant at $1 \%$ level.

Based on the regression analysis, R-squared is 0.24 ; the coefficients of internationalization and diversification are approximately 0.042 and 0.36 , respectively. The coefficients of internationalization are both positive in the three Models. When we use both of them in Model 1, they are statistically significant. We conclude that internationalization and diversification have a positive effect on the leverage ratio of Turkish firms; these results support our two main hypotheses $(\mathrm{H} 1, \mathrm{H} 2)$.

As for the control variables, our regression analysis shows that all control variables were significant at a $10 \%$ level in our empirical study, and only six variables out of seven were significant $(p<0.05)$. In Model 4 only control variables were taken; the coefficients of tangibility, profitability, and liquidity are found to be negative, whereas the coefficient of ownership concentration, size, and growth opportunity are found to be positive at a 5\% level. Although, non-debt tax shield has a negative coefficient with a leverage ratio but is significant $(\mathrm{p}<$ 0.1 ) in all models.

\section{Discussion of the Results}

Previous finance literature stated the strategy of firms as an important factor that may affect a firm's financial leverage. Previous studies (Williamson, 1988; Kochhar \& Hitt, 1998; Ramli et al., 2016; Bandyopadhyay \& Barua, 2016; Duran \&Stephen, 2020; Harper, \& Sun, 2020; Cappa et al., 2020) focused on the impact of strategic decisions on financial leverage in different countries such as Italy, USA, the UK, China, Malaysia, and some African countries, whereas our study focused on the Turkish market that has been neglected by previous studies. Most of the previous studies (Chkir \& Cosset,2003; Harrison et al., 2004; Rocca, et al., 2009; Lucey \&Zhang, 2011; Jouida, 2018; Lindner et al., 2018; Dinh et al., 2019; Duran \&Stephen, 2020) considered only one dimension of corporate strategy. Our study, however, examined both internationalization and diversification strategies simultaneously and independently. The outcomes of our empirical study confirm the assumptions of the behavioral theory of capital structure (Barton \&Gordon, 1988) through proving the effect of corporate strategy on an organization's financial leverage even controlling the firm specific factors that might affect the leverage of a firm.

Our outcomes confirm the predictions of trade-off theory's that assumed the ownership of international firms of subsidiaries in different markets for advantageous tax rates or interest deduction laws. Hence, they are more able to leverage on tax shield advantages maximization (Mansi \&Reeb, 2002; Joliet \& Muller, 2013). Moreover, these results are in the line with the interpretation of Duran and Stephen (2020) who have proved that international firms can get an advantage by having access to low interest rates in the global capital markets, however, domestic firms, do not have access to these international capital markets, thus, they are generally characterized by a less amount of debt, Internationalization also provides a benefit of cash flow diversification. The result of our panel analysis is in line with what has been discovered by Gönenç and Arslan (2003); international firms in the Turkish market have a higher debt ratio than domestics ones.

Moreover, our results show that the diversification strategy also has a positive effect on the firm's financial leverage, which confirms the findings of previous studies (Cappa, Cetrini, \&Oriani, 2019; Singh et al., 2003; Kwok \& Reeb, 2000; Chkir\& Cosset, 2001) who finds a positive relation between leverage and diversification. Also, these results are in line with the perspective of the co-insurance effect and the transaction cost explanation diversification can improve a firm's debt capacity by reducing business risks (Bergh 1997; Williamson, 1988); When a firm diversifies its activities it has the potential to eliminate risks that are faced by firms operating in a sole domain, thus increasing their capacity for debt (Lewellen, 1971; Kim and McConnell, 
1977). Operating in more than one sector leads to higher stability of cash flow and thus higher sustainability of leverage (Williamson, 1988). Moreover, the findings of the current study confirm the Agency theory predictions regarding the positive correlation between diversification and leverage.

Finally, in terms of the control variables included in our model, our empirical data confirms the significant impact on organizational capital structure by ownership concentration, liquidity, non-debt tax shield, profitability, tangibility, growth opportunity, and the size of the organization. In terms of the association between liquidity and leverage, our empirical finding detected a negative relationship, which is consistent with the finding of several studies (Ozkan, 2001; Viviani, 2008; Güner, 2015; Ramli et al., 2017; Cappa et al., 2020) who found that liquidity and debt ratios are negatively correlated. Additionally, our results confirm the assumptions of pecking order theory of lower debt level for high liquidity level organizations. Profitability also has a negative effect on the debt ratio, which assures the position of pecking order theory on the preference of internal financing by organizations with good profits in order to eliminate the need for external financing. Moreover, the current findings confirm the ones of similar literature (Ozkan, 2001; Bayrakdaroğlu et al., 2013; Acaravci, 2015; Cappa et al., 2020). Regarding tangibility, our findings show that tangibility and leverage are negatively correlated; our result confirms Turkish existing research (Gönenç\& Arslan, 2003; Sayilgan et al., 2006; Arilyn, 2020; Bayrakdaroğlu et al., 2013).

Concerning ownership concentration, current findings show that Turkish organizations are highly concentrated, and the debt ratio of Turkish firms is positively influenced by ownership concentration. Our findings are consistent with several previous studies (Gönenç \& Arslan, 2003; Pindado \& La Torre, 2011; Ozili \& Uadiale, 2017; Migliardo \& Forgione, 2018) and are also supported the monitoring arguments which stated that shareholders owning the highest shares would be able to impose their monitoring and controlling policies on management. Therefore, debt can be used as an internal disciplinary tool. As well our results supported the argument of Driffield et al., (2007) who claimed that power-centered organizations that mainly those that have high ownership concentration - family or government ownership - to not lose this power, debt financing is preferred. In terms of growth opportunity; our findings show that leverage is positively coefficient with growth opportunity, our result confirms the suggestion of pecking order theory that claims organizations may need to look for external funds to finance their growth; as a result, debt levels can be elevated in organizations having higher growth potentials (Myers, 1977). Our results confirm literature findings claiming that growth opportunity is positively related to leverage ratio (Sayilgan et al., 2006; Bayrakdaroğlu et al., 2013; Köksal et al., 2013; Acaravc1, 2015). Regarding the relation between leverage and size, our result confirms trade-off theory's perspective on large companies' owning more proportion of debt ratio due to lower non-payment risk. The empirical result of our study confirms the outcomes of existing literature (Rajan \& Zingales, 1995; Gaud et al., 2005; Sayılgan et al., 2006; Coleman et al., 2016; Singh, 2016; Dinçergök, 2017), whose results detected a positive relationship between the size of the firm and leverage. Finally, our findings show that nondebt tax shield and leverage are negatively correlated at a 10\% level of significance; our findings are in the line with the predictions of DeAngelo and Masulis (1980) who suggest that firms with higher non-debt tax shields are expected to have lower leverage than firms with lower non-debt tax shields. In addition, current empirical results are consistent with the outcomes of existing literature on Turkish market (Sayilgan et al., 2006; Bayrakdaroğlu et al., 2013).

\section{CONCLUSION}

Capital structure is deemed a significant topic in financial literature since decades. Several research were conducted regarding the determining factors of capital structure. In particular, while majority of the literature focused mainly on relations between firm-specific characteristics with financial leverage, very few studies focused on the relation between corporate strategy and an organization's leverage within developed and emerging markets. Moreover, most previous studies have conducted research on the relationships between one aspect of corporate strategy and a firm's leverage at a time, our study considered the effect of two strategies. This study examined the corporate strategies under two subsections - internationalization and diversification strategies - and seven more factors potentially impacting firm's capital structure were chosen as control variables. Existing empirical evidence indicates that of the study internationalization and diversification have a positive effect on a firm's leverage. Alternatively, international organizations have the tendency for higher level of debt than domestic and diversified firms employ debt more than non-diversified 
ones. According to control variables our results detected, six out of seven variables - tangibility, ownership concentration, size, liquidity, growth opportunity, and profitability - are deemed as substantial determinants for Turkish organization's capital structure.

This study considered the simultaneous impact of two strategies at the corporate level (internationalization and diversification) on the capital structure. Further studies may include the third strategy namely; integration strategy in their analysis.

\section{References}

Abdul-Qadir, A. B., Yaroson, E. V., \& Abdu, M. (2015). Institutional Investors, Board Size and Capital Structure Decisions: Empirical Evidence from Non-Financial Firms in Nigeria. European Journal of Business and Management, 7(23), 82-90.

ACARAVCI, S. K. (2015). The Determinants of Capital Structure: Evidence from the Turkish Manufacturing Sector. International Journal of Economics and Financial Issues, 5(1), 158-171.

Acedo_Ramírez, M. A., \& Ruiz_Cabestre, F. J. (2014). Determinants of Capital Structure: the United Kingdom versus Continental European Countries. Journal of International Financial Management \& Accounting, 25(3), 237-270.

Ahmad pour, A., Samimi, A. J., \&Golmohammadi, H. (2012). Corporate Governance and Capital Structure: Evidence from Tehran Stock Exchange. Middle-East Journal of Scientific Research, 11(4), 531-535.

Ajay, R., \&Madhumathi, R. (2012). Diversification Strategy and Its Influence on the Capital. International Journal of Social Science and Humanity.

Allen, D. E., \& Mizuno, H. (1989). The determinants of corporate capital structure: Japanese evidence. Applied Economics, 21(5), 569-585.

Amit, R., \&Livnat, J. (1989). Efficient Corporate Diversification: Methods and Implications. Management Science, 35(7), 771-902.

Arilyn, E. J. (2020). The influence of profitability, asset tangibility, firm size, liquidity, and agency conflict toward capital structure on food and beverage companies listed in Indonesia stock exchange. Journal of Emerging Economies \& Islamic Research, 8(1), 1-8.

Arsov, S., \&Naumoski, A. (2016). Determinants of capital structure: An empirical study of companies from selected post-transition economies. Journal of Economics and, 34(1), 119-146.

Attar, A. (2014). Corporate Strategy and Capital Structure: An Empirical Study of Listed Manufacturing Firms in Saudi Arabia. http://bura.brunel.ac.uk/handle/2438/8761.

Barton, S. L., \& Gordon, P. J. (1988). Corporate strategy and capital structure. Strategic Management Journal, 9(6), 623-632.

Bauer, P. (2004). Determinants of Capital Structure: Empirical Evidence from the Czech Republic. Czech Journal of Economics and Finance (Finance auver), 54(1-2), 2-21.

Bayrakdaroğlu, A. E. (2013). A panel data analysis of capital structure determinants: empirical results from Turkish capital market. International Journal of Economics and Finance, 5(4), 131-140.

Bergh, D. D. (1997). Predicting divestiture of unrelated acquisitions: an integrative model of ex ante conditions.Strategic Management Journal, 18(9), 715-731.

Bhaduri, S. N. (2002). Determinants of capital structure choice: a study of the Indian corporate sector. Applied Financial Economics, 12(9), 655-665.

Boussaada, R., \&Karmani, M. (2015). Ownership Concentration and Bank Performance: Evidence from. International Journal of Business and Management, 10(3), 189-202.

Bradley, M., Jarrell, G. A., \& Kim, E. H. (1984). On the Existence of an Optimal Capital Structure: Theory and Evidence. The Journal of Finance, 39(3), 857-878.

Brush, T. H., Bromiley, P., \&Hendrickx, M. (2000). The free cash flow hypothesis for sales growth and firm performance. Strategic Management Journal, 21(4), 455-472.

Cappa, F., Cetrini, G., \&Oriani, R. (2020). The impact of corporate strategy on capital structure: evidence from Italian listed firms. The Quarterly Review of Economics and Finance, 76, 379-385. 
CEYLAN, I. E. (2018). Impact of Ownership Concentration on Capital Structures: A Case of. Optimum Journal of Economics and Management Sciences, 5(2), 193-204.

Chatterjee, S., \&Wernerfelt, B. (1991). The link between resources and type of diversification: Theory and evidence. Strategic Management Journal, 12(1), 33-48.

Chkir, I., \& Cosset, J._C. (2003). The Effect Of International Acquisitions on Firm Leverage. The Journal of Financial Research, 26(4), 501-515.

Coleman, S., Cotei, C., \& Farhat, J. (2016). The debt equity financing decisions of U.S. startup firms. Journal of Economics and Finance, 40, 105-126.

DeAngelo, H., \&Masulis, R. W. (1980). Optimal capital structure under corporate and personal taxation. Journal of Financial Economics, 8(1), 3-29.

Deesomsak, R., Paudyal, K., \&Pescetto, G. (2004). The determinants of capital structure: evidence from the Asia Pacific region. Journal of Multinational Financial Management, 14(4-5), 387-405.

Dinçergök, B. (2017). The Effect of Firm Size on Capital Structure Decisions: An Application on BIST Manufacturing Sector Firms. Journal of Business Research- Turk, 9(2), 89-109.

Dinh, H. P., Nguyen, P. V., \& Hosseini, J. C. (2019). The impact of product diversification and capital structure on firm performance: evidence from Vietnamese manufacturing enterprises. Journal for Global Business Advancement, 12(1).

Dirk, B., Abe de, J., \&Kees, K. (2006). Capital structure policies in Europe: Survey evidence. Journal of Banking \& Finance, 30(5), 1409-1442.

Dobusch, L., \&Kapeller, J. (2018). Open strategy making with crowds and communities: Comparing Wikimedia and Creative Commons. Long Range Planning, 51(4), 561-579.

Doukas, J. A., \&Pantzalis, C. (2003). Geographic diversification and agency costs of debt of multinational firms. Journal of Corporate Finance, 9(1), 59-92.

Driffield, N., Mahambare, V., \& Pal, S. (2007). How does ownership structure affect capital structure and firm value? Economics of Transition becomes Economics of Transition and Institutional Change, 15(3), 535573.

Duran, M. M., \& Stephen, S.-A. (2020). Internationalization and the capital structure of firms in emerging markets: Evidence from Latin America before and after the financial crisis. Research in International Business and Finance, 54.

Fattouh, B., Scaramozzino, P., \& Harris, L. (2002). Capital structure in South Korea: a quantile regression approach. Royal Economic Society Annual Conference, 70, 1-34.

FRIEND, I., \& LANG, L. H. (1988). An Empirical Test of the Impact of Managerial SelfInterest on Corporate Capital Structure. The Journal of Finance, 43(2), 271-281.

Gaud, P., Jani, E., Hoesli, M., \& Bender, A. (2005). The Capital Structure of Swiss Companies: an Empirical Analysis Using Dynamic Panel Data. European Financial Management, 11(1), 51-69.

Gill, A., Bige, N., \& Mathur, N. (2011). The Effect of Capital Structure on Profitability: Evidence. International Journal of Management, Vol. 28 No. 4 Part 1, pp. 3-15.

Gonenc, H., \& Arslan, O. (2003). Capital Structure of the Turkish Domestic and International Real Sector Firms. Istanbul Stock Exchange Review, 7, 41-64.

Grier, P., \&Zychowicz, E. J. (1994). Institutional investors, corporate discipline, and the role of debt. Journal of Economics and Business, 46(1), 1-11.

Güner, A. (2015). The Determinants of Capital Structure Decisions: New Evidence from Turkish Companies. Procedia Economics and Finance, 38, 8489.

Hardiningsih, P., \&Oktaviani, R. M. (2012).DeterminanKebijakanHutang (Dalam Agency Theory and Pecking Order Theory). DinamikaAkuntansi, Keuangan dan Perbankan,1(1), 11-24.

Harrison, A. E., Love, I., \& McMillan, M. S. (2004). Global capital flows and financing constraints. Journal of Development Economics, 75(1), 269-301.

Hitt, M. A., Hoskisson, R. E., \& Ireland, R. D. (1994). A Mid-Range Theory of the Interactive Effects of International and Product Diversification on Innovation and Performance. JOURNAL OF MANAGEMENT, 20(2). 
HUANG, G., \& SONG, F. M. (2006). The determinants of capital structure: Evidence from China. China Economic Review, 17(1), 14-36.

Iswarini, T., \&Ardiansari, A. (2018). The Effect of Ownership Structure, Profitability, Firm Size, and Tangibility on Capital Structure. Management Analysis Journal, 7(4), 494-505.

Jaisinghani, D. (2016). Impact of R\&D on profitability in the pharma sector: an empirical study from India. Journal of Asia Business Studies, 10(2), 194-210.

Javorcik, B. S., \&Spatareanu, M. (2009). Liquidity Constraints and Firms' Linkages with Multinationals. The World Bank Economic Review, 23(2), 323-346.

Jensen, M. C. (1986). Agency Costs of Free Cash Flow, Corporate Finance, and Takeovers. American Economic Association Quarterly, 76(2), 323-329.

Jensen, M. C., \&Meckling, W. H. (1976). Theory of the firm: Managerial behavior, agency costs, and ownership structure. Journal of Financial Economics, 3(4), 305-360.

Johanson, J., \& Vahlne, J.-E. (1997). The Internationalization Process of the Firm - A Model of Knowledge Development and Increasing Foreign Market Commitments. Journal of International Business Studies, $8,23-32$.

Johnson, S., Porta, R. L., Lopez-de-Silanes, F., \& Shleifer, A. (2000). Tunneling. American Economic Review, 90(2), 22-27.

Joliet, R., \& Muller, A. (2013). Capital structure effects of international expansion. Journal of Multinational Financial Management, 23(5), 375-393.

Jouida, S. (2018). Diversification, capital structure, and profitability: A panel VAR approach. Research in International Business and Finance, 45, 243-256.

Kashefi-Pour, E., Lasfer, M., \&Carapeto, M. (2010). The Determinants of Capital Structure across Firms' Sizes: The UK Main and AIM Markets Evidence.

Kim, B., \& Lee, I. (2003). Agency problems and performance of Korean companies during the Asian financial crisis: Chaebol vs. non-chaebol firms. Pacific-Basin Finance Journal, 11(3), 327-348.

Kim, E. H., \& McConnell, J. J. (1977). Corporate Mergers and The Co-Insurance of Corporate Debt. The Journal of Finance, 32(2), 349-365.

KIRACI, K., \& AYDIN, N. (2018). Determinants of Capital Structure: Empirical evidence from traditional Airlines. International Journal of Economic \& Administrative Studies, 21, 173-186.

Kochhar, R., \&Hitt, M. A. (1998). Linking corporate strategy to capital structure: diversification strategy, type, and source of financing. Strategic Management Journal, 19(6), 601-610.

Köksal, B., Orman, C., \&Oduncu, A. (2013). Determinants of Capital Structure: Evidence from a Major Emerging Market Economy. Munich Personal RePEc Archive Paper No. 48415.

Kwok, C. C., \&Reeb, D. M. (2000). Internationalization and Firm Risk: An Upstream Downstream Hypothesis. Journal of International Business Studies, 31, 611-629.

Laksana, I. F., \&Widyawati, D. (2016).PengaruhKepemilikan Saham, KebijakanDividen, Tangibility, Size, and ProfitabilitasTerhadapStruktur Modal. JournalIlmu dan RisetAkuntansi, 5(4), 1-18.

Lee, K. C., \& Kwok, C. C. (1988). Multinational Corporations vs. Domestic Corporations: International Environmental Factors and Determinants of Capital Structure. Journal of International Business Studies, $19,195-217$.

Lewellen, W. G. (1971). A Pure Financial Rationale for the Conglomerate Merger. The Journal of Finance, 26(2), 521-537.

Lim, E. N._K., Das, S. S., \& Das, A. (2009). Diversification strategy, capital structure, and the Asian financial crisis (1997-1998): evidence from Singapore firms. Strategic Management Journal, 30(6), 577-594.

Lindner, T., Klein, F., \& Schmidt, S. (2018). The effect of internationalization on firm capital structure: A metaanalysis and exploration of institutional contingencies. International Business Review, 27(6), 1238-1249.

Low, P. Y., \& Chen, K. H. (2004). Diversification and Capital Structure: Some International Evidence. Review of Quantitative Finance and Accounting, 23, 55-71.

Lowe, J., Naughton, T., \& Taylor, P. (1994). The impact of corporate strategy on the capital structure of Australian companies. Management and Decision, 15(3), 245-257.

Lucey, B. M., \& Zhang, Q. (2011). Financial integration and emerging markets capital structure. Journal of Banking \& Finance, 35(5), 1228-1238. 
Migliardo, C., \&Forgione, A. F. (2018). Ownership structure and bank performance in EU-15 countries. Corporate Governance, 18(3), 509-530.

Myers, S. (1977). Determinants of corporate borrowing. Journal of Financial Economics, 5(2), 147175.

Myers, S. C., \&Majluf, N. S. (1984). Corporate financing and investment decisions when firms have information that investors do not have. Journal of Financial Economics, 13(2), 187-221.

Namara, A. M., Murro, P., \&O'Donohoe, S. (2017). Countries lending infrastructure and capital structure determination: The case of European SMEs. Journal of Corporate Finance, 43, 122-138.

Nguyen, V. C. (2020). Human capital, capital structure choice and firm profitability in developing countries: An empirical study in Vietnam. Growing Science, 6(2), 127-136.

Oktovianti, T., \&Agustia, D. (2012). Influence of the Internal Corporate Governance and Leverage Ratio to the Earnings Management. Journal of Basic and Applied, 2(7), 7192-7199.

Omet, G. (2006). Ownership Structure and Capital Structure: Evidence from the Jordanian Capital Market (1995-2003). Corporate Governance and Control, 3(4), 99-107.

Ozili, P. K., \&Uadiale, O. (2017). Ownership concentration and bank profitability. Future Business Journal, $3(2), 159-171$.

Ozkan, A. (2001). Determinants of Capital Structure and Adjustment to Long Run Target: Evidence from UK Company Panel Data. Journal of Business Finance \& Accounting, 28(1-2), 175-198.

Pacheco, L., \& Tavares, F. (2015). Capital structure determinants of Portuguese footwear sector SMEs: Empirical evidence using panel data. Tékhne, 13(2), 145-157.

Pagan, A. R., \& Hall, A. D. (1983). Diagnostic tests as residual analysis. Econometric Reviews, 2(2), 159-218.

Psillaki, M., \& Daskalakis, N. (2008). Are the determinants of capital structure country or firm. Small business economics, 33, 319-333.

Puragand, M. B., \& Abdullah, A. B. (2016). Corporate governance and capital structure of Malaysian familyowned companies. Journal of Business and Retail Management Research, 11(1), 18-30.

Purkayastha, S., Manolova, T. S., \& Edelman, L. F. (2012). Diversification and Performance in Developed and Emerging Market Contexts: A Review of the Literature. International Journal of Management Reviews, 14, 18-38.

Rajan, R. G., \& Zingales, L. (1995). What Do We Know about Capital Structure? Some Evidence from International Data. The Journal of Finance, 50(5), 1421-1460.

Ramli, N. A., Latan, H., \&Solovida, G. T. (2019). Determinants of capital structure and firm financial performance - A PLS-SEM approach: Evidence from Malaysia and Indonesia. The Quarterly Review of Economics and Finance, 71, 148-160.

Rocca, M. L., Rocca, T. L., Gerace, D., \&Smark, C. (2009). Effect of diversification on capital structure. Accounting and Finance, 49(4), 799-826.

Rumelt, R. P. (1974). Strategy, Structure, and Economic Performance. Cambridge Massachusetts: Harvard University.

Sayılgan, G., Karabacak, H., \&Küçükkocaoglu, G. (2006). The Firm-Specific Determinants of Corporate Capital Structure: Evidence from Turkish Panel Data. Investment Management and Financial Innovations, 3(3), 125139.

Sbeti, W. M., \&Moosa, I. (2012). Firm-specific factors as determinants of capital structure in the absence of taxes. Applied Financial Economics, 22(3), 209-213.

Schmidheiny, K. (2017). Emerging Lessons from Half a Century of Fiscal Federalism in Switzerl and swiss. Journal of Economics and Statistics, 153(2), 73 - 101.

Shah, M. H., \& Khan, S. (2017). Factors Effecting Commercial Banks Profitability in Pakistan. Journal of Business and Tourism, 3(1), 1-12.

Shleifer, A., \&Vishny, R. W. (1986). Large Shareholders and Corporate Control. Journal of Political Economy, 94(3).

Sibilkov, V. (2009). Asset Liquidity and Capital Structure. The Journal of Financial and Quantitative Analysis, 44(5), 1173-1196.

Singh, D. (2016). A Panel Data Analysis of Capital Structure Determinants: An. International Journal of Economics and Financial, 6, 1650-1656. 
Singh, M., \&Nejadmalayeri, A. (2004). Internationalization, capital structure, and cost of capital: evidence from French corporations. Journal of Multinational Financial Management, 14(2), 153-169.

Singh, M., III, W. N., \&Suchard, J.-A. (2003). Corporate diversification strategies and capital structure. The Quarterly Review of Economics and Finance, 43(1), 147-167.

Stohs, M. H., \& Mauer, D. C. (1996). The Determinants of Corporate Debt Maturity Structure. The Journal of Business, 69(3), 279-312.

Taub, A. J. (1975). Determinants of the Firm's Capital Structure. The Review of Economics and Statistics, 57(4), 410-416.

Tomak, S. (2013). Determinants of Commercial Banks? Lending Behavior: Evidence from Turkey. Asian Journal of Empirical Research, 3(8), 933-943.

Tong, G., \& Green, C. J. (2007). Pecking order or trade-off hypothesis? Evidence on the capital structure of Chinese companies. Applied economics, 2179-2189.

Umer, U. (2014). Determinants of Capital Structure: Empirical Evidence from Large Taxpayer Share Companies in Ethiopia. International Journal of Economics and Finance, 6(1).

Vivian, J..L. (2008). Capital structure determinants: an empirical study of French companies in the wine industry. International Journal of Wine Business Research, 2.

Vo, X. V. (2020). Foreign Investors and Stock Price Crash Risk: Evidence from Vietnam. International review of finance, 993-1004.

Wahab, S. N., \& Ramli, N. A. (2013). Determinants of Capital Structure: An Empirical Investigation of Malaysian Listed Government Linked Companies (GLCs). International Journal of Economics and Financial Issues, 4(4), 930-945.

Wald, J. K. (1999). How Firm Characteristics Affect Capital Structure: An International Comparison. The Journal of Financial Research, XXII (2), 161-187.

Welch, L. S., \&Luostarinen, R. (1988). Internationalization: Evolution of a Concept. Journal of General Management, 14(2), 34-55.

WILLIAMSON, O. E. (1988). Corporate Finance and Corporate Governance. The journal of Finance, 43(3), 567591.

Wiwattanakantang, Y. (1999). An empirical study on the determinants of the capital structure of Thai firms. Pacific-Basin Finance Journal, 7(3-4), 371-403.

Wyrobek, J., \& Lane, P. (2019). Impact of Internationalization on the Capital Structure of Commercial Companies. PolitykiEuropejskie, Finansei Marketing, 22(71), 250-267.

Yeyati, E. L., \&Micco, A. (2007). Concentration and foreign penetration in Latin American banking sectors: Impact on competition and risk. Journal of Banking and Finance, 31(6), 1633-1647. 